Chapter 4

\title{
Corrosion Behaviour of Cold-Deformed Austenitic Alloys
}

\author{
Wojciech Ozgowicz, Agnieszka Kurc-Lisiecka and \\ Adam Grajcar
}

Additional information is available at the end of the chapter

http://dx.doi.org/10.5772/53590

\section{Introduction}

Austenitic stainless steels are the most important group of corrosion-resistant metallic materials finding widespread industrial application. The material has been employed in many applications ranging from pharmaceutical equipment to piping in the nuclear reactors. The microstructure of the austenitic stainless steels is composed of the monophase austenite $(\gamma)$, and the steels generally have low $\left(\sim 16 \mathrm{mJm}^{-2}\right)$ or medium $\left(\sim 20 \mathrm{mJm}^{-2}\right)$ values of the stacking fault energy (SFE). Plastic deformation of these steels leads to a phase transformation from paramagnetic austenite into ferromagnetic martensite. Depending on the chemical composition, stacking fault energy, phase stability and deformation conditions (temperature, strain rate and strain value) different transformations can take place (i.e., $\gamma \rightarrow \varepsilon, \gamma \rightarrow \varepsilon \rightarrow \alpha^{\prime}$ or $\gamma \rightarrow \alpha^{\prime}$ ) in metastable austenitic steels. At the early stage of deformation, shear bands consisting of stacking faults and deformation twins are formed, promoted by the low SFE of these steels. The $\varepsilon$-martensite phase is formed by overlapping stacking faults, and therefore, it is finely dispersed and its structure is heavily faulted. The crystal structure of $\alpha^{\prime}$-martensite is bodycentered cubic, and it is usually nucleated at the intersections of shear bands. The volume fractions and distribution of individual phases influence mechanical properties and corrosion resistance of these steels.

Literature data show (Zhilin et al., 2006; Kumar et al., 2007; Rutkowska-Gorczyca et al., 2009) that the cold deformation of Cr-Ni steels worsens their corrosion resistance. It can be explained for several ways. The delivering to material additional energy as a result of the induction of external tensions is generally accepted as one of the causes of the lowering of corrosion resistance. It leads in consequences to decreasing the thermodynamic durability of the material. The second reason is connected with the crystallographic structure of cold-de- 
formed material which shows the characteristic orientation of grains (texture). Crystallographic texture plays an important role altering pitting mechanism, possibly by reducing favorable sites for corrosion attack and formation of Cr-rich passive film favored by highdensity close-packed planes oriented parallel to the rolling surface (Kumar et al.; 2005).

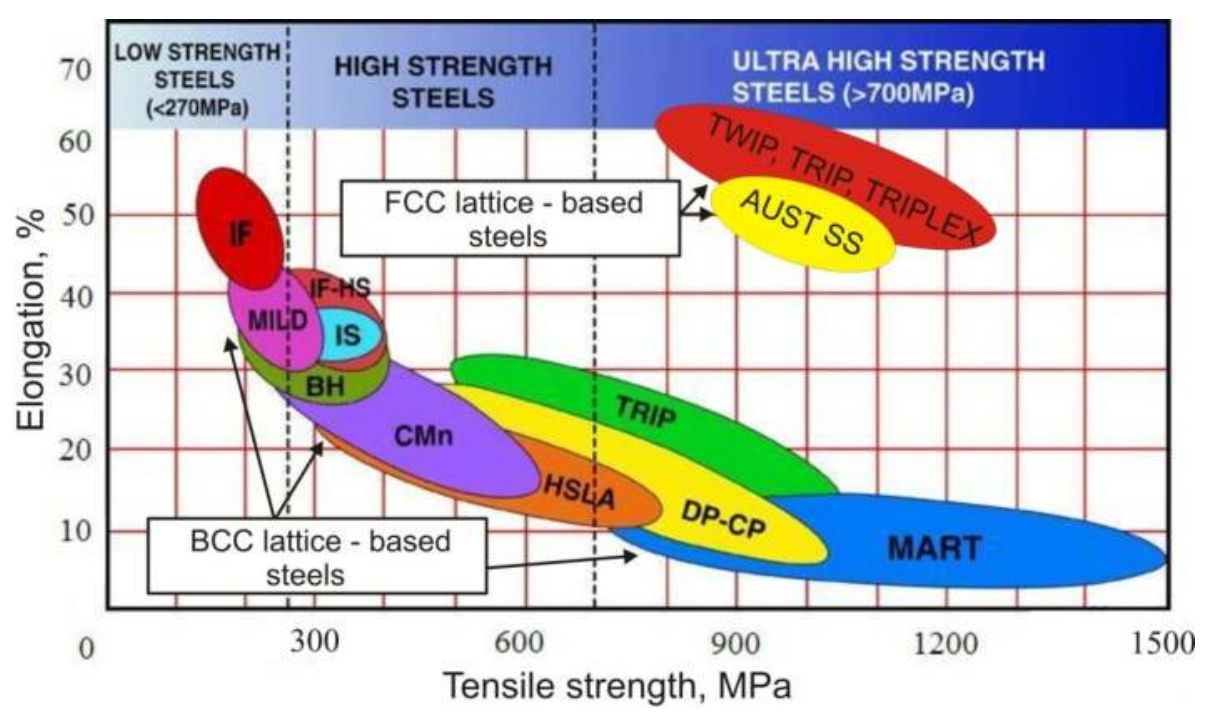

Figure 1. Schematic comparison of mechanical properties of conventional and advanced BCC lattice-based steels with Cr-Ni (AUST SS) and high-Mn (TWIP, TRIP, TRIPLEX) austenitic alloys (International Iron \& Steel Institute, 2006).

In some applications the Cr-Ni alloys would be very useful due to their excellent combination of strength, ductility and corrosion resistance but their application is limited because of the high cost. For example, it relates to their potential application in the automotive industry or for cryogenic applications. Austenitic microstructure can be also formed by manganese alloying at much reduced cost. The manganese content guaranteeing an uniform austenitic microstructure is equal to about $25 \%$ for carbon contents between 0.04 and $0.1 \%$ (Frommeyer et al., 2003; Graessel et al., 2000). The manganese content can be decreased to about $17 \%$ for steels with higher carbon concentrations (up to 0.8 wt.\%) (De Cooman et al., 2011; Ghayad et al., 2006; Jimenez \& Frommeyer, 2010). Sometimes, high-manganese steels contain up to 4\% $\mathrm{Al}$ and/or Si (Frommeyer et al., 2003; Graessel et al., 2000), chromium (Hamada, 2007; Mujica Roncery et al., 2010) or microadditions of Nb, Ti and B (Grajcar et al., 2009, 2010a, 2010b; Huang et al., 2006). Independently of a chemical composition, different grades of both high-manganese and $\mathrm{Cr}-\mathrm{Ni}$ austenitic steels offer an exceptional combination of high-strength and ductility compared to conventional and advanced BCC lattice-based steels (Fig. 1). The source of unique mechanical properties and technological formability of austenitic alloys is the great susceptibility of $\gamma$ phase on plastic deformation, during which dislocation glide, mechanical twinning (TWIP - Twinning Induced Plasticity) and/or straininduced martensitic transformation (TRIP - TRansformation Induced Plasticity) can occur. 
The key to obtain the mechanical properties range in Fig. 1 is the high work hardening rate characterizing the plastic deformation of austenitic alloys. The high level of ductility is a result of delaying necking during straining. In case of the local presence of necking, strain-induced martensitic transformation occurs in such places (in TRIP steels) or deformation twins are preferably generated in locally deformed areas (in TWIP steels). It leads to intensive local strain hardening of the steel and further plastic strain proceeds in less strain-hardened adjacent zones. The situation is repeated in successive regions of the material what finally leads to delaying necking in a macro scale and high uniform and total elongation (De Cooman et al., 2011; Frommeyer et al., 2003; Grajcar, 2012). The shear band formation accompanied by dislocation glide occurs in deformed areas of TRIPLEX steels and the SIP (Shear band Induced Plasticity) effect is sustained by the uniform arrangement of nano size $\kappa$-carbides coherent to the austenitic matrix (Frommeyer \& Bruex, 2006).

\section{Corrosion behaviour of austenitic alloys}

\subsection{Cr-Ni austenitic steels}

Corrosion resistance of stainless steels is achieved by dissolving a sufficient content of chromium in iron to produce a coherent, adherent, insulating and regenerating chromium oxide protective film $\left(\mathrm{Cr}_{2} \mathrm{O}_{3}\right)$ on a surface. The stainless character occurs when the concentration of $\mathrm{Cr}$ exceeds about $12 \mathrm{wt} \%$. The passive film of chromium oxide formed in air at room temperature is only about 1-2 $\mathrm{nm}$. However, this is not adequate to resist corrosion in acids such as $\mathrm{HCl}$ or $\mathrm{H}_{2} \mathrm{SO}_{4}$ (Azambuja et al., 2003; Kurc et al., 2010). In environments containing chloride the austenitic steels are susceptible to localized corrosive attacks, such as pitting corrosion, intergranular corrosion and stress corrosion cracking (SCC) (Osawa \& Hasegawa, 1981; Ningshen et al., 2010).

Pitting corrosion is the result of the local destruction of the passive film and subsequent corrosion of the steel below. It generally occurs in chloride, halide or bromide solutions. It can be initiated at a fault in the passive layer or at a surface defect. Pitting is considered to be autocatalytic in nature; once a pit starts to grow, the conditions developed are such that further pit growth is promoted. The anodic and cathodic electrochemical reactions that comprise corrosion separate spatially during pitting. The local pit environment becomes depleted in cathodic reactant (e.g., oxygen), which shifts most of the cathodic reaction to the boldly exposed surface where this reactant is more plentiful. The pit environment becomes enriched in metal cations and anionic species such as chloride, which migrate into the pit to maintain charge neutrality by balancing the charge associated with the cation concentration (Frankel, 1998). Even in a neutral solution, this can cause the $p H$ to drop locally to 2 or 3 , thereby preventing the regeneration of the passive layer. In the passive condition, the current density is of the order of $\mu \mathrm{A} \mathrm{cm}^{-2}$. However, it may exceed $1 \mathrm{~A} \mathrm{~cm}^{-2}$ in the pit. The reason why the current density is so large in the pit is that the anodic region is a very small area when compared with the cathodic part (the steel free of the pits). For a given corrosion current, this greatly exaggerates the corrosion rate at the pits. Similarly, the concentration of 
chloride ions in the vicinity of a pit can be thousands of times greater than that in the solution as a whole (Otero et al., 1995; Padro et al., 2007).

The anodic dissolution of steel leads to introduction of positive metal ions $\left(\mathrm{M}^{+}\right)$into solution, which causes migration of $\mathrm{Cl}^{-}$ions. In turn, metal chloride reacts with water according to the reaction (1):

$$
\mathrm{M}^{+} \mathrm{Cl}^{-}+\mathrm{H}_{2} \mathrm{O} \rightarrow \mathrm{MOH}+\mathrm{H}^{+} \mathrm{Cl}^{-}
$$

This causes the $p H$ to decrease. The cathodic reaction, on the surface near the pit follows (2):

$$
\mathrm{O}_{2}+2 \mathrm{H}_{2} \mathrm{O} \rightarrow \mathrm{MOH}+4 \mathrm{OH}^{-}
$$

Pitting is mainly associated with microscopic heterogeneities at a surface rather than macroscopic physical features of a component. Wet and humid environments containing chloride ions can cause pitting corrosion and crevice corrosion of austenitic stainless steel components. Chloride ions are known to be potent corrosion enhancers and localized adsorption of chloride ions can act as prenuclei for pitting. Pits can also nucleate at carbides, grain boundaries and other material inhomogenities on the metal surface. The presence of moisture in the environment can also facilitate the electrolytic path for the chloride ions (Khatak \& Raj, 2002).

The corrosion behaviour of hydrogen-containing austenitic stainless steels has also been studied and it has become clear that the intergranular corrosion (Sunada et al., 2006) and the general corrosion (Osawa \& Hasegawa, 1981; Sunada et al., 2006) were accelerated by hydrogenation. This phenomenon was noticed by the authors as "anomalous corrosion". Anomalous general corrosion of austenitic stainless steels is observed when steels contain stress-induced martensite. These BCC regions become anodically active sites due to hydrogenation and are attacked selectively. On the other hand, the stress induced martensite plays an important role during crack initiation and propagation processes when stress corrosion cracking in $\mathrm{H}_{2} \mathrm{SO}_{4}-\mathrm{NaCl}$ solution occurs. Osawa \& Hasegawa (1981) investigated the corrosion behaviour of hydrogen-containing deformed austenitic stainless steels and observed

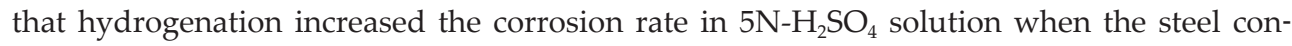
tained stress-induced martensite. They found that the corrosion rate increases with increasing the volume fraction of martensite and hydrogenation facilitates this tendency. The similar effect of stress induced martensite on stress corrosion cracking of the 304 and 310 stainless steels was observed by Qiao \& Luo (1998).

\subsection{High-Mn austenitic steels}

The research on high-Mn-Al alloys for cryogenic applications that were supposed to substitute $\mathrm{Cr}-\mathrm{Ni}$ steels was carried out in the eighties of the last century (Altstetter et al., 1986). The role of manganese is to replace $\mathrm{Ni}$ and to obtain an austenitic microstructure, whereas aluminium has a similar impact as chromium. Improvement of corrosion resistance by $\mathrm{Al}$ 
consists in formation of thin stable layer of oxides. Alstetter et al. (1986) found that high-Mn$\mathrm{Al}$ alloys show inferior corrosion resistance than $\mathrm{Cr}-\mathrm{Ni}$ steels and they can be used as a substitute only in some applications. Nowadays, the application of high-Mn austenitic steels in the automotive industry rises and some works are undertaken to improve the corrosion resistance of these alloys.

The addition of $25 \% \mathrm{Mn}$ to mild steels was found to be very detrimental to the corrosion resistance in aqueous solutions (Zhang \& Zhu, 1999). The Fe-25Mn alloy was difficult to passivate, even in $1 \mathrm{M} \mathrm{Na}_{2} \mathrm{SO}_{4}$ solution. With increasing $\mathrm{Al}$ content up to $5 \%$ of the $\mathrm{Fe}-25 \mathrm{Mn}-\mathrm{Al}$ steel, the anodic polarization curves exhibit a stable passivation region in $\mathrm{Na}_{2} \mathrm{SO}_{4}$ solution, but it shows no passivation in $3.5 \mathrm{wt} \% \mathrm{NaCl}$ solution. Recently, corrosion resistance of Fe-0.05C-29Mn-3.1Al-1.4Si steel in acidic $\left(0.1 \mathrm{M} \mathrm{H}_{2} \mathrm{SO}_{4}\right)$ and chloride-containing (3.5 $\mathrm{wt} \%$ $\mathrm{NaCl}$ ) environments was investigated by Kannan et al. (2008). They found that the high-MnAl-Si steel has lower corrosion resistance than an ultra deep drawing ferritic steel, both in acidic and chloride media. The corrosion resistance of the high-manganese steel in chloride solutions is higher compared to that observed in acidic medium.

The behaviour of Fe-0.2C-25Mn-(1-8) Al steels with increased concentration of $\mathrm{Al}$ up to $8 \%$ in $3.5 \mathrm{wt} \% \mathrm{NaCl}$ was also investigated by Hamada (2007). It was reported that the corrosion resistance of tested steels in chloride environments is pretty low. The predominating corrosion type is the general corrosion, but locally corrosion pits were observed. In steels including up to $6 \% \mathrm{Al}$ with homogeneous austenite structure, places where the pits occur are casually, whereas in case of two-phase structure, including ferrite and austenite (Fe-0.2C-25Mn-8Al), they preferentially occur in $\alpha$ phase. It was found that complex addition of $\mathrm{Al}$ and $\mathrm{Cr}$ to $\mathrm{Fe}-0.26 \mathrm{C}-30 \mathrm{Mn}-4 \mathrm{Al}-4 \mathrm{Cr}$ and $\mathrm{Fe}-0.25 \mathrm{C}-30 \mathrm{Mn}-8 \mathrm{Al}-6 \mathrm{Cr}$ alloys increases considerably the general corrosion resistance, especially after anodic passivation ageing of surface layers in an oxidizing electrolytic solution (Hamada, 2007). Cr-bearing steels passivated by nucleation and growth of the passive oxide films on the steel surface, where the enrichment of $\mathrm{Al}$ and $\mathrm{Cr}$ and depletion of $\mathrm{Fe}$ and $\mathrm{Mn}$ have occurred. The positive role of $\mathrm{Cr}$ in obtaining passivation layers in $0.5 \mathrm{M} \mathrm{H}_{2} \mathrm{SO}_{4}$ acidic solution was recently confirmed by Mujica Roncery et al. (2010) in Fe-25Mn-12Cr-0.3C-0.4N alloy.

\subsection{Effect of cold deformation}

Stainless steels are usually subjected to different levels of cold working during final manufacturing stages. Cold deformation affects the corrosion resistance of stainless steels because planar dislocation arrays (Oh \& Hong, 2000) and deformation twins (Lee et al., 2007) are introduced. Barbucci et al. (2002) reported that the passive currents in both sulfate + chloride and sulfuric acid solutions significantly increased with increasing the degree of cold working of the 304 type stainless steel. The pitting susceptibility also increased with cold working, especially evident as the chloride concentration increased. The dependence of the pitting potential on cold working was explained using the bilayer model, the sulfate ingresses in the passive film during anodic oxidation forming a coulombic barrier against chloride penetration. On the basis of microscopic examination after long time polarization in $1 \mathrm{M}$ $\mathrm{H}_{2} \mathrm{SO}_{4}$ acidic solution it was found, that the surface profile of the passive film depended on 
the metallurgical structure of a metallic substrate. The higher passive currents and increased susceptibility to pitting corrosion of the work hardened samples were explained by the formation of much more defective oxides during its anodic oxidation, with easy paths that enhanced sulfate ingress. The growth of such oxides was related to the formation of defects in the grains and more defective interfaces in the bulk material, resulting from the accumulation of internal stresses during cold rolling (Barbucci et al., 2002).

Efforts have been also made to clarify the relationship between cold working and a sensitization process. Briant (1982) observed a transgranular attack in the 304 type stainless steel due to strain-induced martensite. However, a similar corrosion attack has been also noted in the deformed 316 type stainless steel consisting of an uniform austenitic microstructure. The cold working effect in the 316 type steel has been attributed to higher diffusivity of chromium and the lower free energy barrier to carbide nucleation at grain boundaries in the deformed microstructure. The acceleration of sensitization due to cold deformation could be also related to the effects of point defects and microstructural sinks on diffusion (Fu et al., 2009).

The influence of cold working, in particular the amount of $\alpha^{\prime}$ martensite on the behaviour of AISI 321 stainless steel in $3.5 \mathrm{wt} \% \mathrm{NaCl}$ was studied by Xu et al. (2004). They showed that when the content of martensite was less than $6 \%$ and more than $22 \%$, the pitting sensitivity increased. However, when the martensite content was between 6 and 22\%, the sensitivity decreased with increasing its content. Fang et al. (1997) reported that the corrosion potential of the martensite phase was more negative than that of austenite and this is the primary reason for the selective corrosion of martensite. They also demonstrated that the pitting potential of the austenite phase was more noble than that of the martensite phase and the stable passive current of austenite was lower compared to martensite.

Sunada et al. (1991) found that the number of pits formed on AISI 304 austenitic stainless steel in $\mathrm{H}_{2} \mathrm{SO}_{4}-\mathrm{NaCl}$ solution had a direct relationship with the martensite content. The effect of $\alpha^{\prime}$ phase on the number of pits depended upon the $\mathrm{NaCl}$ concentration, temperature and potential. In the case of high $\mathrm{NaCl}$ concentration, the degree of pitting increased linearly with increasing volume fraction of martensite. Under high temperature and high anodic potential conditions, the number of pits was almost constant in the range of volume fractions greater than $50 \%$. The corrosion rate of the martensitic phase was about 1.65 times that the magnitude of the austenitic phase at volume fractions of martensite below $50 \%$. At volume fractions higher than 50\%, the corrosion rate was more enhanced. Peguet et al. (2007) studied the influence of cold rolling with 10,20, 30 and 70\% reduction on the pitting corrosion of AISI 304 stainless steels. Electrochemical tests were carried out in $0.5 \mathrm{M} \mathrm{NaCl}$. They showed, that the pit propagation rate increases monotonously with cold rolling and the pit repassivation ability decreases (leading to a larger number of stable pits), suggesting that the overall dislocation density is the most important controlling factor.

The influence of cold deformation on corrosion behaviour in $3.5 \mathrm{wt} \% \mathrm{NaCl}$ in high-Mn steels was studied by Ghayad et al. (2006). They found that the 0.5C-29Mn-3.5Al-0.5Si steel shows no tendency to passivation, independently on the steel structure after heat treatment (supersaturated, aged or strain-aged). Higher corrosion rate of cold worked specimens compared to that in the supersaturated state, was a result of faster steel dissolution caused by 
annealing twins, which show a different potential than the matrix. The highest corrosion rate was observed in strain-aged samples, as a result of ferrite formation, which creates a corrosive galvanic cell with the austenitic matrix. High-Mn steels containing hydrogen-induced or strain-induced $\varepsilon / \alpha^{\prime}$ martensite are also susceptible to hydrogen embrittlement (Lovicu et al., 2010) and delayed fracture (De Cooman et al., 2011; Shin et al., 2010).

\section{Experimental procedure}

\subsection{Material}

The chapter addresses the corrosion behaviour of cold-deformed $\mathrm{Cr}-\mathrm{Ni}$ and high-Mn austenitic steels in chloride and acidic media. The chemical composition of the investigated steels is presented in Table 1.

\begin{tabular}{ccccccccccccc}
\hline Steel grade & $\mathbf{C}$ & $\mathbf{M n}$ & $\mathbf{S i}$ & $\mathbf{P}$ & $\mathbf{S}$ & $\mathbf{N}$ & $\mathbf{C r}$ & $\mathbf{N i}$ & $\mathbf{M o}$ & $\mathbf{A l}$ & $\mathbf{N b}$ & $\mathbf{T i}$ \\
\hline X5CrNi18-8 & 0.030 & 1.31 & 0.39 & 0.030 & 0.004 & 0.0440 & 18.07 & 8.00 & 0.25 & - & - & - \\
\hline X6MnSiAl26-3-3 & 0.065 & 26.0 & 3.08 & 0.004 & 0.013 & 0.0028 & - & - & - & 2.87 & 0.034 & 0.009 \\
\hline
\end{tabular}

Table 1. Chemical composition of the investigated steels, wt.\%

The microstructure of the stainless steel in a delivery state (after solution heat treatment) is shown in Fig. 2. The X5CrNi18-8 steel exhibits a homogeneous austenite structure with annealing twins (Fig. 2a). The X-ray diffraction analysis confirms the single-phase structure of the steel (Fig. 2b). The high-Mn steel is characterized also be the single-phase austenitic microstructure containing many annealing twins (Fig. 3). The grain sizes of both steels are similar, i.e., from 15 to $30 \mu \mathrm{m}$. The grains of X6MnSiAl26-3-3 steel are slightly elongated as a result of hot rolling followed by solution heat treatment from a temperature of $850^{\circ} \mathrm{C}$.

The stainless steel used for the investigation was delivered in a form of sheet segments with

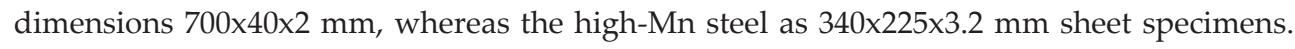
The Cr-Ni steel specimens were subjected to cold rolling with the various amount of deformation ranging from $10 \%, 20 \%, 30 \%, 40 \%, 50 \%$ to $70 \%$. The cold rolling was conducted at room temperature keeping a constant direction and a side of the rolled strip.

Cold deformation of high-manganese steel specimens was applied by bending at room temperature. The samples with a size of $10 \times 15 \mathrm{~mm}$ and a thickness of $3.2 \mathrm{~mm}$ were bent to an angle of $90^{\circ}$ with a bending radius of $3 \mathrm{~mm}$.

The immersion tests and potentiodynamic polarization tests were used to assess the corrosion resistance of austenitic steels in the delivery state and after cold deformation. 
a)
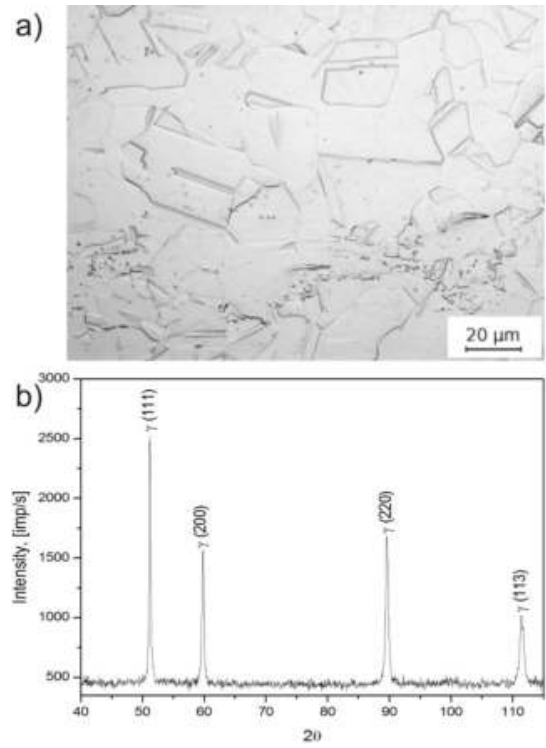

Figure 2. Austenitic microstructure with annealing twins of $X 5 \mathrm{CrNi18-8}$ steel in a delivery state (a) and X-ray diffraction pattern (b).

a)
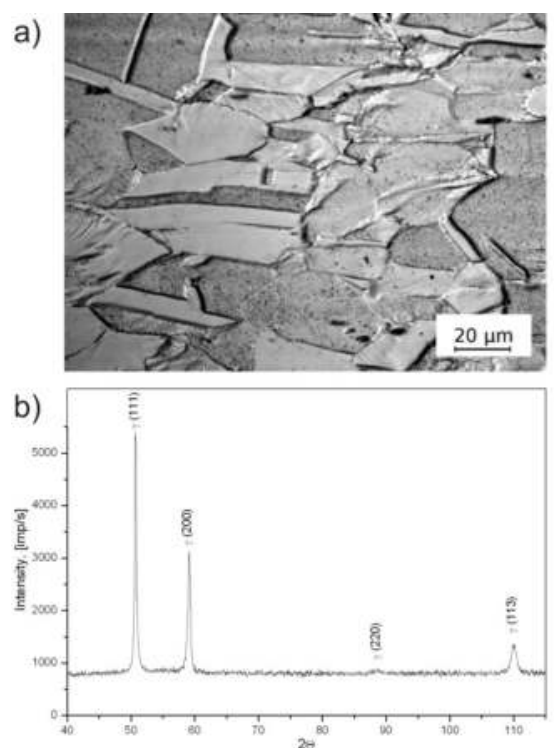

Figure 3. Austenitic microstructure with annealing twins of X6MnSiAl26-3-3 steel after the thermo-mechanical rolling and immersion in $1 \mathrm{~N} \mathrm{H}_{2} \mathrm{SO}_{4}$ (a) and X-ray diffraction pattern (b). 


\subsection{Immersion tests}

The corrosion resistance of the investigated steels was assessed using immersion tests in sulfuric acid and chloride solutions. $3.5 \mathrm{wt} \% \mathrm{NaCl}$ solution was used for both steels whereas $3.5 \mathrm{~N} \mathrm{H}_{2} \mathrm{SO}_{4}$ and $1 \mathrm{~N} \mathrm{H}_{2} \mathrm{SO}_{4}$ solutions were used respectively for $\mathrm{Cr}-\mathrm{Ni}$ and high-Mn steels for the sake of high difference in a corrosion progress. Corrosion tests of the austenitic stainless steel were carried out on samples with dimensions 20×15 mm, whereas 10x15 mm samples were cut for the high-Mn steel. The specimens were taken from the material in the delivery state as well as from sheets after all subsequent deformation stages. Before starting the analysis the samples were washed in distilled water, ultrasonically cleaned in acetone and finally cleaned in $95.6 \%$ ethanol. The specimens were weighed with the accuracy of $0.001 \mathrm{~g}$ and put into solution at room temperature. The time of the test for the stainless steel was equal to 87 days for $3.5 \mathrm{wt} \% \mathrm{NaCl}$ solution and 25 days in the case of $3.5 \mathrm{~N} \mathrm{H}_{2} \mathrm{SO}_{4}$. The majority of samples was dipped entirely whereas a few samples were immersed only partially to compare dipped and original surfaces. Taking into account much faster corrosion rate of the high-Mn steel, it was put into $3.5 \mathrm{wt} \% \mathrm{NaCl}$ and $1 \mathrm{~N} \mathrm{H}_{2} \mathrm{SO}_{4}$ solutions for 4 days. After the tests the specimens were weighed and analyzed using optical microscopy and SEM. Corrosion loss was calculated in a simple way as the difference between initial and final mass of the samples. Percentage mass decrement was also calculated.

Metallographic observations of non-metallic inclusions and corrosion pits were carried out on polished sections, whereas the microstructure observations on specimens etched in nital (high-Mn steel) or in chloroazotic acid (Cr-Ni steel). The investigations were performed using LEICA MEF 4A optical microscope, with magnifications from 100 to 1000x. Fractographic investigations were carried out using scanning electron microscope SUPRA 25 (Zeiss) at the accelerating voltage of $20 \mathrm{kV}$. In order to remove corrosion products, the specimens were ultrasonically cleaned before the analysis.

\subsection{Potentiodynamic polarization tests}

Investigation of the electrochemical corrosion behaviour of the stainless steel samples was done in a PGP 201 potentiostat using a conventional three-electrode cell consisting of a saturated calomel reference electrode (SCE), a platinum counter electrode and the studied specimens as the working electrode (Fig. 4). The results of the electrochemical corrosion behaviour of the high-Mn steel are presented elsewhere (Grajcar, 2012). The tests were carried out at room temperature in the electrolyte simulating sea water $(3.5 \mathrm{wt} \% \mathrm{NaCl})$ on specimens of size $30 \times 20 \mathrm{~mm}$ with an exposed sample area of about $1 \mathrm{~cm}^{2}$. Registering of anodic polarization curves was conducted at the rate equal to $1 \mathrm{mV} / \mathrm{s}$. The measurement of corrosion potential was realized in time of $60 \mathrm{~min}$. According to registered curves the corrosion potential $\left(\mathrm{E}_{\text {cor }}\right)$, polarization resistance $\left(\mathrm{R}_{\mathrm{p}}\right)$ and corrosion current density $\left(\mathrm{i}_{\text {cor }}\right)$ were determined. In order to calculate the corrosion current, the Stern-Geary equation was used (Baszkiewicz \& Kamiński, 1997): 


$$
R_{p}=\frac{b_{k} \cdot b_{a}}{2.3 \cdot i_{c o r}\left(b_{a}+b_{k}\right)}\left[k \Omega \cdot \mathrm{cm}^{2}\right]
$$

where: $b_{k}$ - the slope coefficient of the cathodic Tafel line, $b_{a}$ - the slope coefficient of the anodic Tafel line, $\mathrm{i}_{\text {cor }}$ - the corrosion current density $\left[\mu \mathrm{A} / \mathrm{cm}^{2}\right], \mathrm{R}_{\mathrm{p}}$ - the polarization resistance $\left[\mathrm{k} \Omega \mathrm{cm}^{2}\right]$.

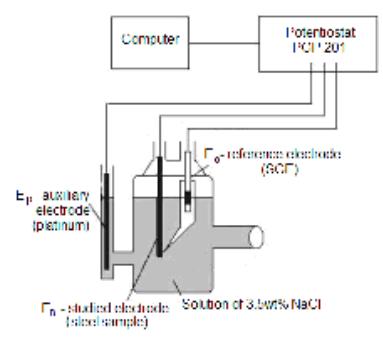

Figure 4. Schematic showing of the corrosion resistance investigation set.

\section{Results and discussion}

\subsection{Cr-Ni austenitic steel}

\subsubsection{Results of immersion tests}

Results of the immersion tests in two media for non-deformed samples are given in Table 2. After immersion in $3.5 \mathrm{~N} \mathrm{H}_{2} \mathrm{SO}_{4}$ the $\mathrm{X} 5 \mathrm{CrNi18}-8$ steel showed a percentage mass decrement about $38 \%$. The mass loss of specimens dipped in $3.5 \mathrm{wt} \% \mathrm{NaCl}$ is over 100 times lower despite longer time of the immersion compared to specimens dipped in the acidic solution. Štefec \& Franz (1978) observed the similar order of magnitude of corrosion progress for the AISI 304 steel. The difference is due to different corrosion mechanisms. When the solution is acidic, the corrosion process is running according to hydrogen depolarization, whereas in chloride media the specimens are corroding with oxygen depolarization.

\begin{tabular}{ccc}
\hline X5CrNi18-8 steel & \multicolumn{2}{c}{ Corrosion medium } \\
\hline State & $3.5 \mathrm{~N} \mathrm{H}_{2} \mathrm{SO}_{4}$ & $3.5 \mathrm{wt} \% \mathrm{NaCl}$ \\
\hline non-deformed & $38.2 \pm 6.3$ & $0.24 \pm 0.08$ \\
\hline $50 \%$ cold deformed & $67.5 \pm 9.8$ & $0.72 \pm 0.23$ \\
\hline
\end{tabular}

Table 2. Mean percentage mass loss of samples in an initial state and 50\% cold-deformed after the immersion tests, $\%$ 
Many micropores and corrosion pits along the whole specimen surface were observed in the X5CrNi18-8 steel immersed in 3.5 $\mathrm{N} \mathrm{H}_{2} \mathrm{SO}_{4}$ (Fig. 5). Slightly smaller corrosion pits are formed in specimens after the immersion in $3.5 \mathrm{wt} \% \mathrm{NaCl}$ (Figs. 6 and 7). Places privileged to creation of corrosion pits are aggregations of non-metallic inclusions (Fig. 6). On the steel surface the cracked passive layer and symptoms of intergranular corrosion running along the grain boundaries can be also observed (Fig. 7).

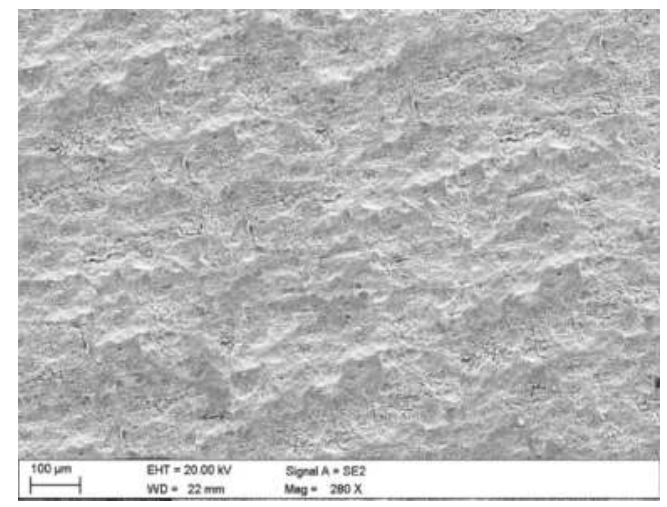

Figure 5. Micropores and corrosion pits on the $\mathrm{X} 5 \mathrm{CrNi18-8}$ steel surface in a delivery state after immersion tests in $3.5 \mathrm{~N} \mathrm{H}_{2} \mathrm{SO}_{4}$ solution.

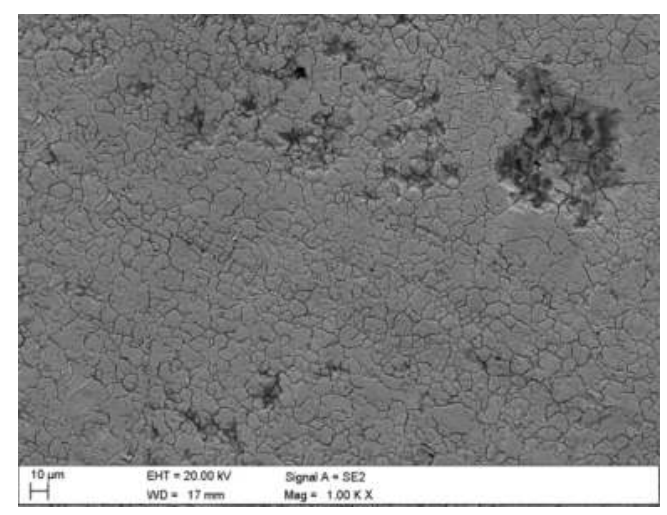

Figure 6. Corrosion pits on the $\mathrm{X} 5 \mathrm{CrNi} 18-8$ steel surface in a delivery state after immersion tests in $3.5 \mathrm{wt} \% \mathrm{NaCl}$ solution.

After cold working with the deformation amount of $50 \%$ and subsequent immersion tests in $3.5 \mathrm{~N} \mathrm{H}_{2} \mathrm{SO}_{4}$ the steel shows a meaningful percentage mass decrement up to $67 \%$ and about two orders of magnitude lower in chloride solution (Table 3). Cold deformation causes the increase of the mass loss both in acidic and chloride media in comparison with the speci- 
mens investigated in the undeformed state (Table 2). In the case of the steel immersed in $3.5 \mathrm{~N} \mathrm{H}_{2} \mathrm{SO}_{4}$ the difference between the mass loss of non-deformed and plastically deformed samples is nearly twice. The mass loss of the cold deformed samples dipped in chloride solution is three times higher. The increasing of mass loss of deformed samples is probably related to the occurrence of strain-induced $\alpha^{\prime}$-martensite (Fig. 8).

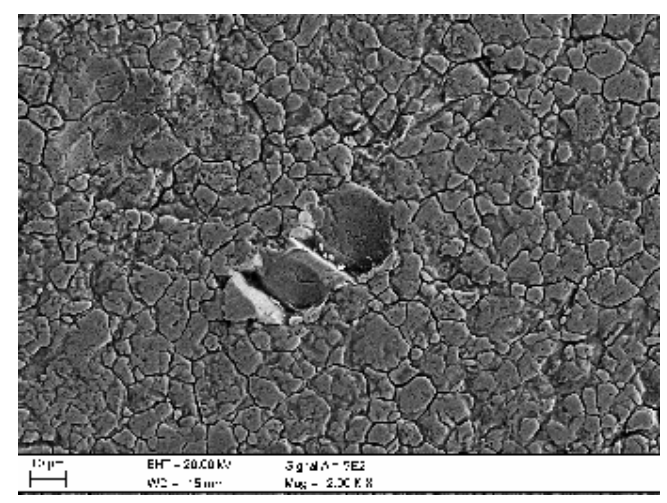

Figure 7. Corrosion pits and the cracked surface layer of the $\mathrm{X} 5 \mathrm{CrNi} 18-8$ steel in a delivery state after immersion tests in $3.5 \mathrm{wt} \% \mathrm{NaCl}$ solution.

The morphology of a surface of the cold-deformed X5CrNi18-8 steel samples after exposition in chloride and acidic media showed a various character of corrosion products (Figs. 9-16). Many corrosion pits of various size can be observed after immersion in the $3.5 \mathrm{~N} \mathrm{H}_{2} \mathrm{SO}_{4}$ solution. In the specimen deformed to $40 \%$ cold reduction wide pits and micropores can be seen (Figs. 9 and 10). The amount and the size of pits are very high and they are formed along the entire surface of specimens. Privileged places for pits forming are surface concentrations of non-metallic inclusions, which are also probable places of hydrogen penetration.

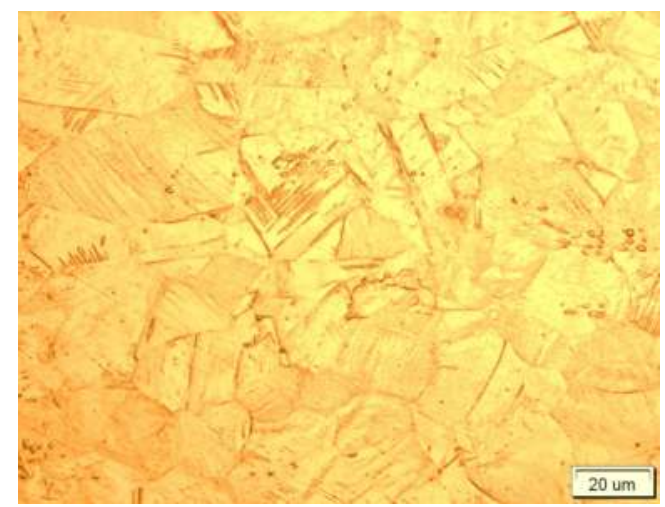

Figure 8. Elongated austenitic grains containing deformation twins and $a^{\prime}$ martensite in the $\times 5 \mathrm{CrNi} 18-8$ steel deformed to the reduction of $30 \%$. 


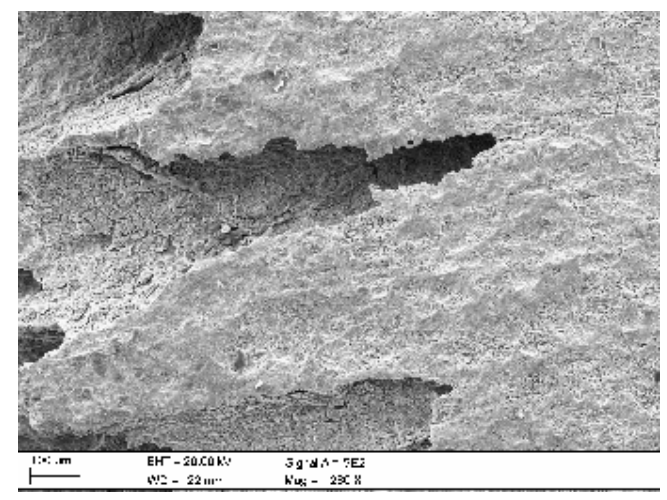

Figure 9. Numerous corrosion pits on the surface of $\mathrm{X} 5 \mathrm{CrNi18}-8$ steel $40 \%$ deformed and immersed in $3.5 \mathrm{~N} \mathrm{H}_{2} \mathrm{SO}_{4}$.

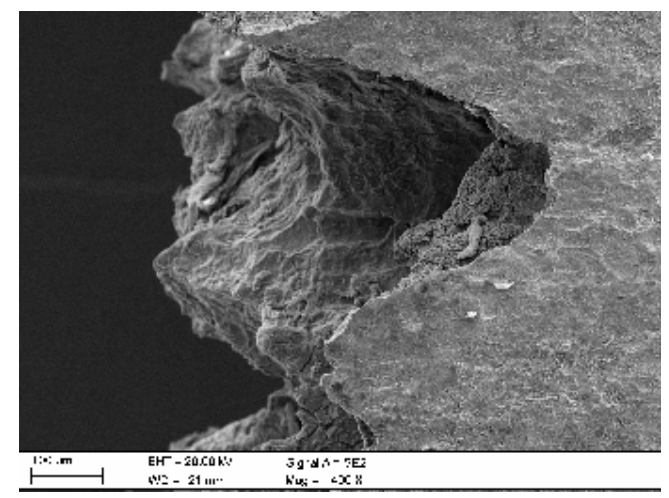

Figure 10. Corrosion pits on the surface of $X 5 \mathrm{CrNi18}-8$ steel $40 \%$ deformed and immersed in $3.5 \mathrm{~N} \mathrm{H}_{2} \mathrm{SO}_{4}$.

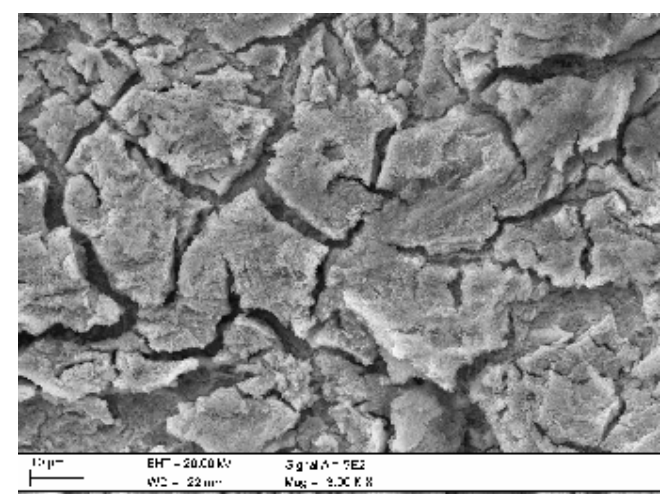

Figure 11. Cracked passive layer on the surface of $X 5 \mathrm{CrNi} 18-8$ steel $40 \%$ deformed and immersed in $3.5 \mathrm{~N} \mathrm{H}_{2} \mathrm{SO}_{4}$. 
Hydrogen can also penetrate deeper into the steel - probably by $\alpha^{\prime}$ martensite laths - accumulating in a surroundings of non-metallic sulfide inclusions (Garcia et al., 2010). Usually, the places of hydrogen accumulation are non-metallic inclusions, grain boundary areas and/or twin boundaries (Abreu et al., 2007; Singh \& Ray, 2007). A cracked passive layer was also observed, what could result in rapid penetration of corrosive medium into interior of the investigated steel (Fig. 11).

The surface of $\mathrm{X} 5 \mathrm{CrNi18}-8$ steel specimens cold rolled in a range from 10 to $70 \%$ and immersed in $3.5 \mathrm{wt} \% \mathrm{NaCl}$ solution for 87 days reveals numerous pits and micropores of diversified size (Figs. 12-15). The presence of corrosion pits in a chloride medium was also confirmed by other authors (Singh et al., 2011; Xu \& Hu, 2004). The pits present on the surface of deformed samples are characterized by bigger sizes compared to the pits observed on undeformed samples (Figs. 6 and 7). Damaging of a superficial layer occurred around the formed pits (Figs. 13 and 14). A cracked passive layer can be also observed. On surfaces of all the investigated samples the traces of intercrystalline corrosion running by the borders of grains and numerous pits with effects of cold rolling are visible (Figs. 12-15).

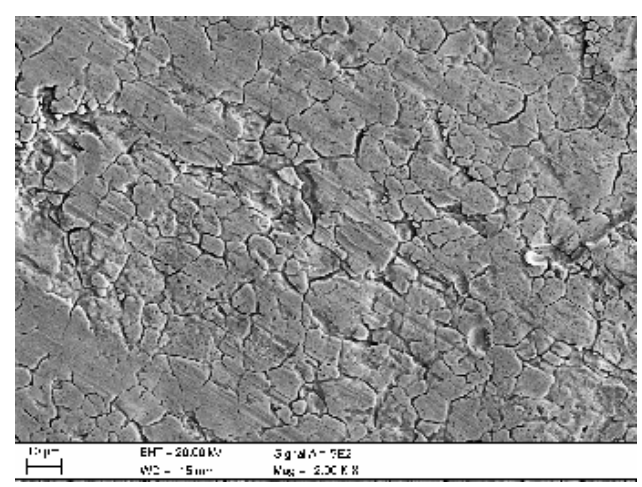

Figure 12. Numerous corrosion pits on the surface of the $\mathrm{X} 5 \mathrm{CrNi} 18-8$ steel $10 \%$ deformed and immersed in $3.5 \mathrm{wt} \%$ $\mathrm{NaCl}$.

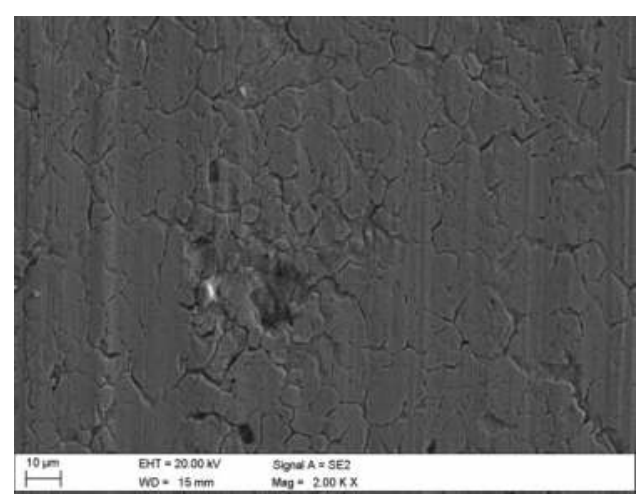

Figure 13. Corrosion pits on the surface of the $\mathrm{X} 5 \mathrm{CrNi} 18-8$ steel $20 \%$ deformed and immersed in $3.5 \mathrm{wt} \% \mathrm{NaCl}$. 


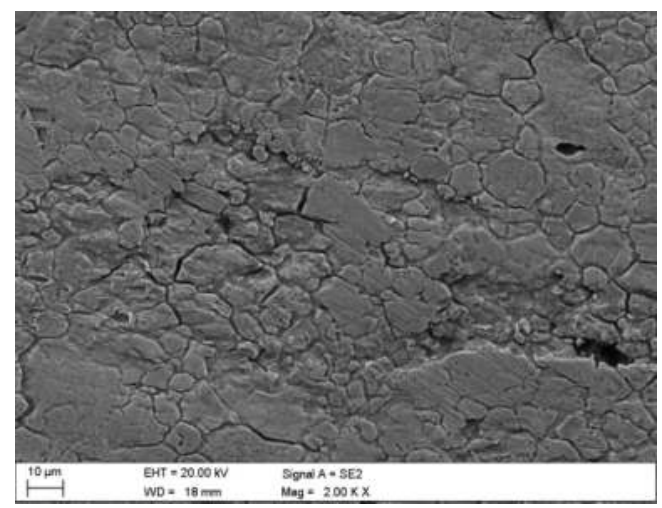

Figure 14. Corrosion pits on the surface of the $\mathrm{X} 5 \mathrm{CrNi} 18-8$ steel $30 \%$ deformed and immersed in $3.5 \mathrm{wt} \% \mathrm{NaCl}$.

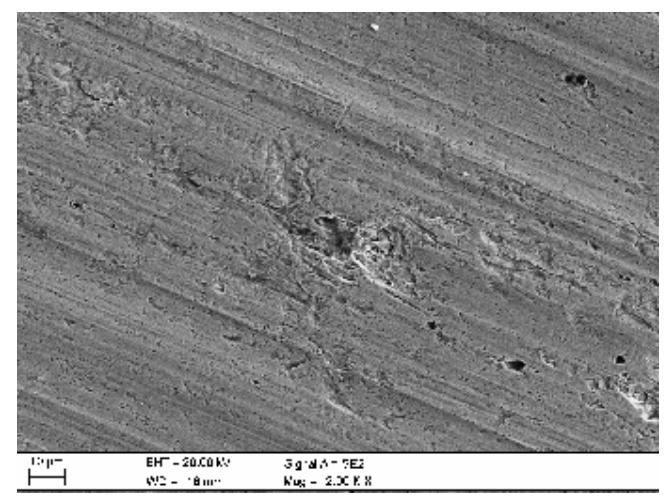

Figure 15. Corrosion pits on the surface of the $\mathrm{X} 5 \mathrm{CrNi} 18-8$ steel $70 \%$ deformed and immersed in $3.5 \mathrm{wt} \% \mathrm{NaCl}$.

The high difference in corrosion behaviour of the stainless steel is due to different corrosion mechanisms in both environments. The big mass loss of the samples in the $\mathrm{H}_{2} \mathrm{SO}_{4}$ solution is due to the hydrogen depolarization mechanism, which is typical for corrosion in acidic media. Hydrogen depolarization is a process of reducing hydrogen ions (from the electrolyte) in cathodic areas by electrons from the metal, to gaseous hydrogen, resulting in continuous flow of electrons outer the metal and consequently the corrosion progress. Due to this process, numerous corrosion pits occur in examined steels (Figs. 5, 9 and 10). Corrosion pits occur intensively in the places containing non-metallic inclusions. They are less precious than the rest of material, fostering potential differences and galvanic cell creation. This causes the absorption of hydrogen ions, which, due to increasing pressure and temperature can recombine to a gaseous form and get out of the metal accompanying formation of corrosion pits. This process is accompanied by local cracking of corrosion products layer (Fig. 11), uncover- 
ing the metal surface and causing further penetration of the corrosive medium and the intensive corrosion progress.

The oxygen depolarization is the main mechanism of the corrosion progress in $\mathrm{NaCl}$ solution. In this process, oxygen included in the electrolyte is being reduced by electrons from the metal to hydroxide ions. On the surface of the alloy appears a layer of corrosion products, protecting the material before further penetration of the corrosion medium. This is why the mass loss in chloride solution is much lower compared to acidic medium (Table 2). At less corrosion-resistant places (e.g. with non-metallic inclusions) potential differences are occurring. This enables the absorption of chloride ions, which form chlorine oxides of increased solubility. It leads to local destructions of corrosion products layer and the initiation of corrosion pits. Further pit expansion is running autocatalytic.

The SEM observations of plastically deformed samples after corrosion tests permit to affirm that plastic deformation results in the significant intensification of the corrosion progress. It can be stated that increasing of cold deformation values from 10 to $70 \%$ leads to the increase of quantity, size and depth of corrosion pits fulfilling a function of a local anode.

\subsubsection{Results of potentiodynamic polarization tests}

Performed electrochemical analysis revealed that the open circuit potential for undeformed and cold deformed samples established itself after $60 \mathrm{~min}$. The change of current density as a function of potential for the undeformed samples investigated in $3.5 \mathrm{wt} \% \mathrm{NaCl}$ solution is presented in Fig. 16. The value of corrosion potential $\mathrm{E}_{\text {cor }}$ was equal $-48 \mathrm{mV}$ and the density of corrosion current $i_{\text {cor }}$ determined basing on the Stern-Geary equation was equal 0.01 $\mu \mathrm{A} / \mathrm{cm}^{2}$. The recorded anodic polarization curve indicates the existence of a passive range. The value of the breakdown potential is equal to $+360 \mathrm{mV}$. When the current density reached $3 \mathrm{~mA} / \mathrm{cm}^{2}$ the direction of anodic polarization of samples was changed. The change of the polarization direction caused the increase of the current density.

The corrosion potential of the $\mathrm{X} 5 \mathrm{CrNi18}-8$ steel cold deformed with the reduction from 10 to $70 \%$ covers the range from -91 to $-51 \mathrm{mV}$ (Fig. 17). The values of corrosion current density were equal to $0.02 \div 1.16 \mu \mathrm{A} / \mathrm{cm}^{2}$ and the breakdown potential changed in the range from +245 to $+348 \mathrm{mV}$. The similar values of the corrosion potential and corrosion current density in a chloride medium for $\mathrm{Cr}-\mathrm{Ni}$ austenitic steels are reported by other authors (RutkowskaGorczyca et al., 2009; Zhilin et al., 2006; Kumar et al., 2007). The changes in the pitting potential, in cold deformed samples, have been reportedly attributable to stresses, strain-induced $\alpha^{\prime}$-martensite or dislocations. The martensite phase can not only cause a decrease in the solution resistance within the pit but also caused a fall in the polarization resistance between metal and a pit. Thus, pit propagation in the 304 stainless steel is accelerated with increasing volume fraction of martensite (Kamide et al., 1994). On the basis of the anodic polarization curves obtained for the investigated $\mathrm{X} 5 \mathrm{CrNi18}-8$ steel it has been found that with increasing the degree of plastic deformation within the range from 10 to $70 \%$ the steel is characterized by the lower values of corrosion potential as well as higher values of corrosion current density (Fig. 17), what proves the intensification of the corrosion progress due to cold working. 


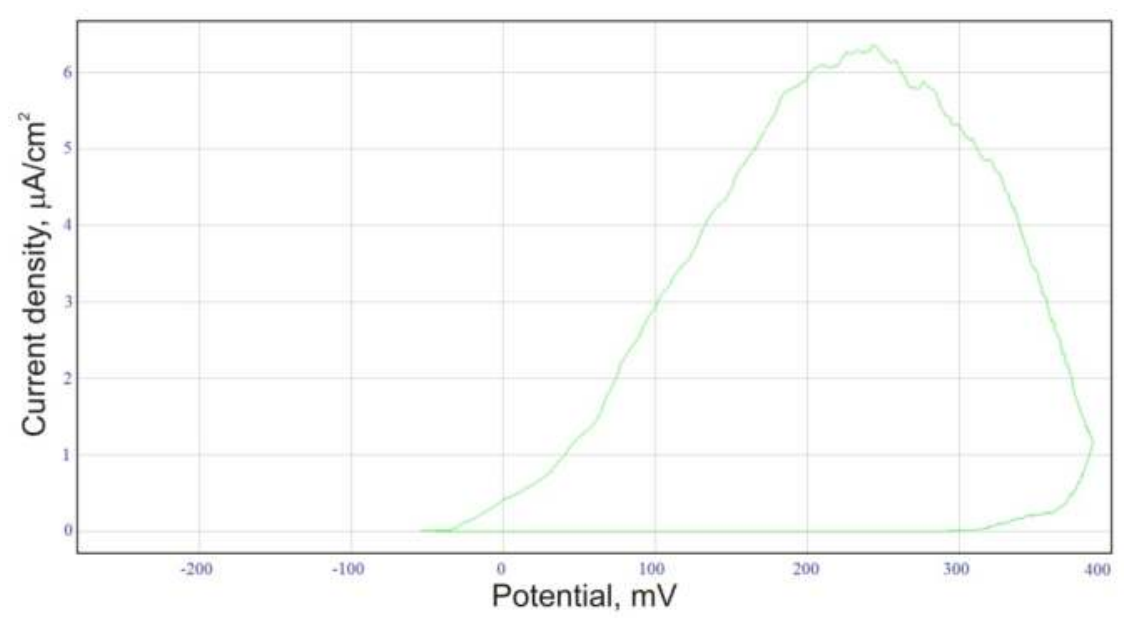

Figure 16. Anodic polarization curve registered for the $\mathrm{X} 5 \mathrm{CrNi} 18-8$ steel in a delivery state in $3.5 \mathrm{wt} \% \mathrm{NaCl}$.

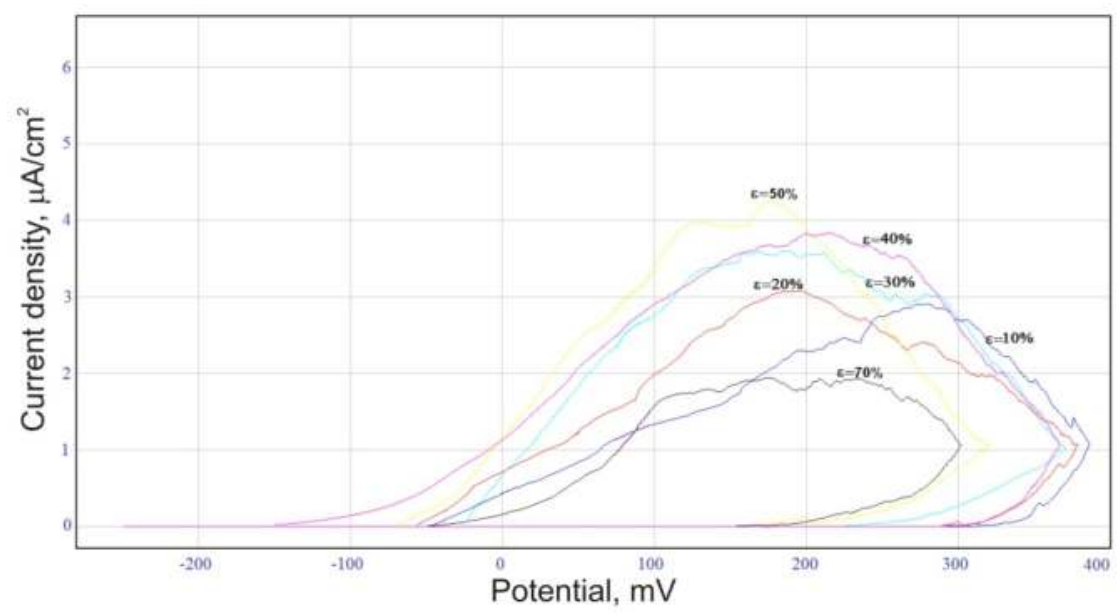

Figure 17. Anodic polarization curves registered for the cold-deformed samples of $\mathrm{X} 5 \mathrm{CrNi} 18-8$ steel in $3.5 \mathrm{wt} \% \mathrm{NaCl}$.

SEM observations of a sample surface after the electrochemical corrosion tests in $3.5 \mathrm{wt} \%$ $\mathrm{NaCl}$ allowed to evaluate the type and degree of corrosion damages. The surface of the X5CrNi18-8 steel in a delivery state is characterized by relatively small corrosion pits and a cracked surface layer (Fig. 18). It is assumed that the surface of the examined samples was subjected to the greatest corrosion attack in places where the local breakdown of the passivation oxide layer in the presence of aggressive anions of the environment has occurred. 


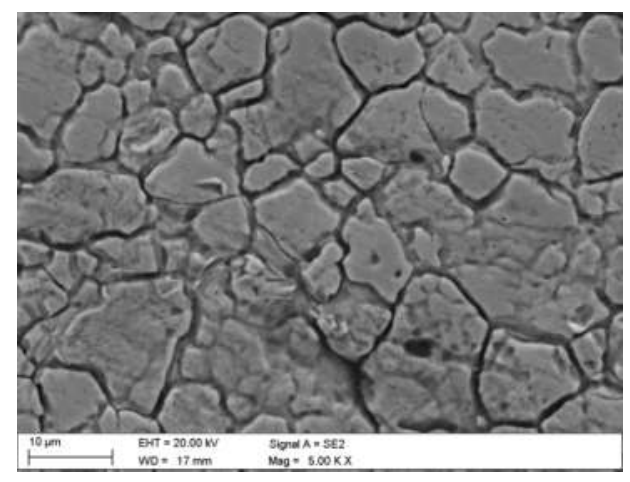

Figure 18. Corrosion pits on the surface of $\mathrm{X} 5 \mathrm{CrNi18-8}$ steel in a delivery state after electrochemical corrosion tests in $3.5 \mathrm{wt} \% \mathrm{NaCl}$ solution.

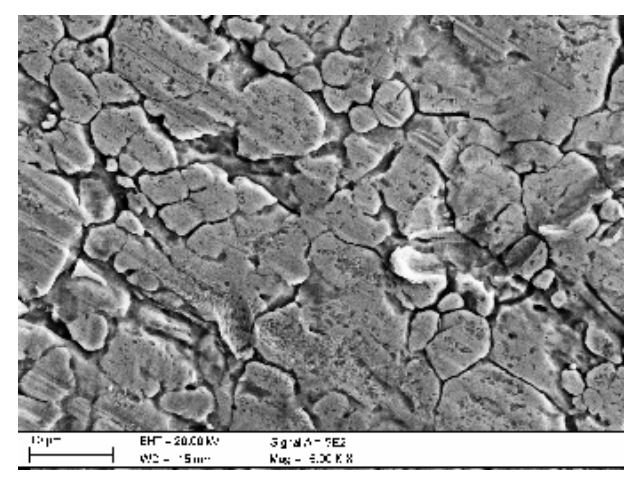

Figure 19. Corrosion pits and the partially cracked surface layer of the $\mathrm{X} 5 \mathrm{CrNi18-8}$ steel $10 \%$ deformed and electrochemically tested in $3.5 \mathrm{wt} \% \mathrm{NaCl}$.

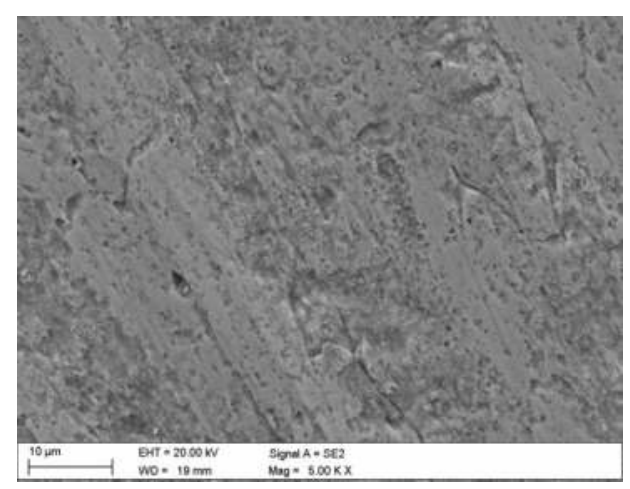

Figure 20. Numerous corrosion pits on the surface of the $\mathrm{X} 5 \mathrm{CrNi} 18-8$ steel $70 \%$ deformed and electrochemically tested in $3.5 \mathrm{wt} \% \mathrm{NaCl}$. 
The surfaces of the electrochemically tested $\mathrm{X} 5 \mathrm{CrNi18}-8$ steel specimens after cold rolling in a range from 10 to $70 \%$ show also numerous pits, micropores and cracks of a surface layer (Figs. 19 and 20). The pits present on the surface of deformed samples are characterized by bigger sizes compared to the pits observed in undeformed samples (Fig. 18). Obtained microstructural results correspond well with those registered for immersion tests.

\subsection{High-Mn austenitic steel}

The results of immersion tests for the high-Mn steel are given in Table 3. After 4 days immersion in $1 \mathrm{~N} \mathrm{H}_{2} \mathrm{SO}_{4}$ the investigated steel shows a significant mass decrement equal to about $38 \%$. Mass loss of samples dipped in a chloride solution is about 100 times lower. The results are similar to these obtained for the stainless steel (Table 2), however, the high-Mn steel corroded to the same extent at much shorter time and under softer acid solution conditions. Therefore, the real corrosion progress of the high manganese steel is much faster compared to the Cr-Ni steel.

\begin{tabular}{ccc}
\hline X6MnSiAl26-3-3 steel & Corrosion medium \\
\hline State & $1 \mathrm{~N} \mathrm{H}_{2} \mathrm{SO}_{4}$ & $3.5 \mathrm{wt} \% \mathrm{NaCl}$ \\
\hline non-deformed & $38.4 \pm 5.2$ & $0.40 \pm 0.03$ \\
\hline cold deformed & $47.5 \pm 1.6$ & $0.33 \pm 0.01$ \\
\hline
\end{tabular}

Table 3. Mean percentage mass loss of samples in an initial state and cold-deformed by bending after the immersion tests, \%

Numerous corrosion pits along the whole specimen surface can be observed after immersion of the $\mathrm{X} 6 \mathrm{MnSiAl} 26-3-3$ steel in $1 \mathrm{~N} \mathrm{H}_{2} \mathrm{SO}_{4}$ (Fig. 21). Slightly smaller corrosion pits are formed in specimens investigated in $3.5 \mathrm{wt} \% \mathrm{NaCl}$. The surface layer of specimens dipped in the acidic medium is characterized by the presence of many cracks and craters formed due to corrosion pitting (Fig. 22). The cracks in the neighbourhood of non-metallic inclusions are also visible in Figure 23 showing the surface of a sample dipped in the chloride solution. Under these conditions, a layer of corrosion products is forming, protecting the steel against further penetration of corrosive medium.

Similar surface defects were also revealed on surfaces of plastically deformed samples. Privileged places for forming of corrosion pits and surface cracks are concentrations of non-metallic inclusions, which are also potential places of hydrogen penetration. Figure 24 presents the plastically deformed austenitic grains containing deformation twins and elongated nonmetallic inclusions. It was observed that hydrogen can penetrate into the steel up to a depth of about $0.3 \mathrm{~mm}$, accumulating usually in a surroundings of elongated sulfide inclusions. Hydrogen failures can be usually observed at non-metallic inclusions and in grain boundary areas (Fig. 24). 


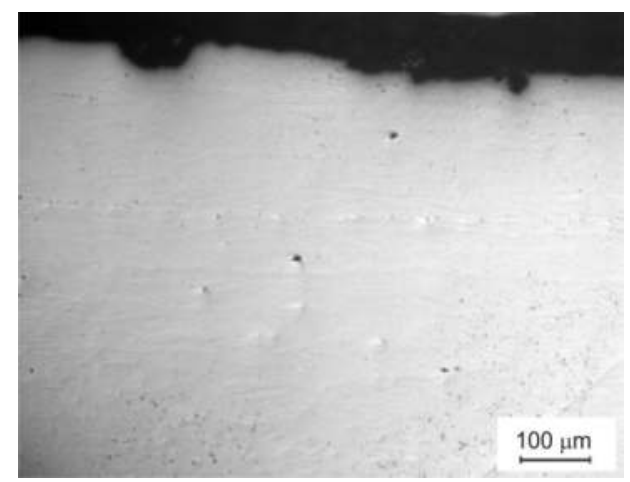

Figure 21. Corrosion pits and non-metallic inclusions in the X6MnSiAl26-3-3 steel after the immersion test in $1 \mathrm{~N} \mathrm{H}_{2} \mathrm{SO}_{4}$.

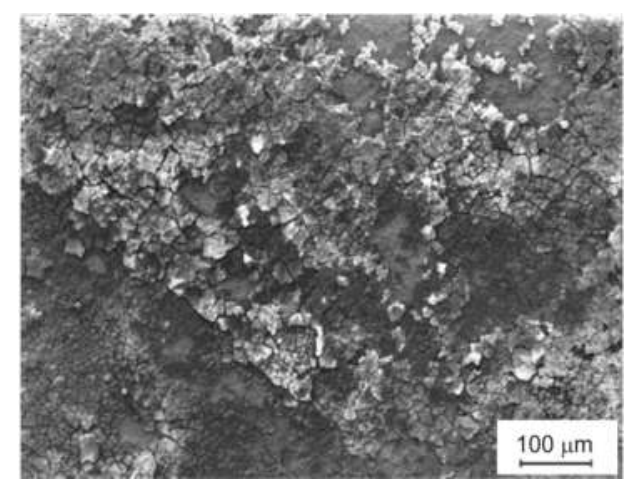

Figure 22. Numerous cracks and craters formed due to corrosion pitting on the surface of the X6MnSiAl26-3-3 steel after the immersion test in $1 \mathrm{~N} \mathrm{H}_{2} \mathrm{SO}_{4}$.

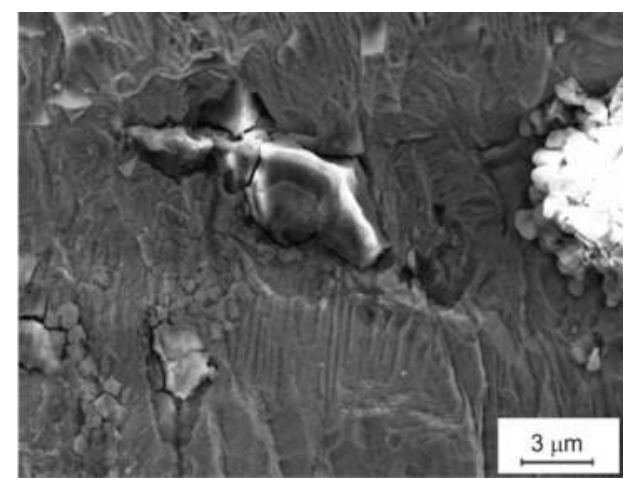

Figure 23. A layer of corrosion products containing surface cracks in the X6MnSiAl26-3-3 steel after the immersion test in $3.5 \mathrm{wt} \% \mathrm{NaCl}$. 


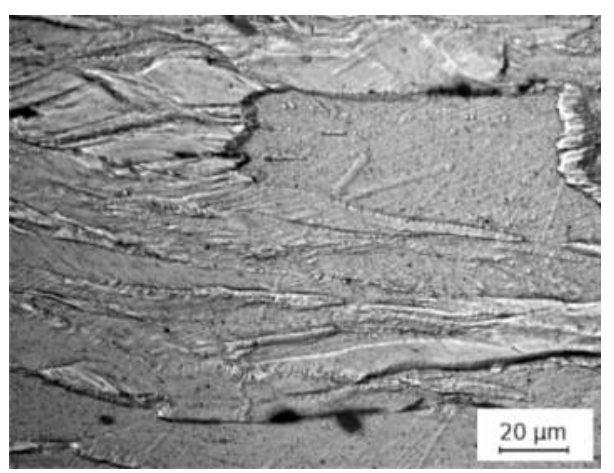

Figure 24. Austenitic grains containing deformation twins, elongated sulfide inclusions and hydrogen failures in the X6MnSiAl26-3-3 steel after bending and immersion in $1 \mathrm{~N} \mathrm{H}_{2} \mathrm{SO}_{4}$.

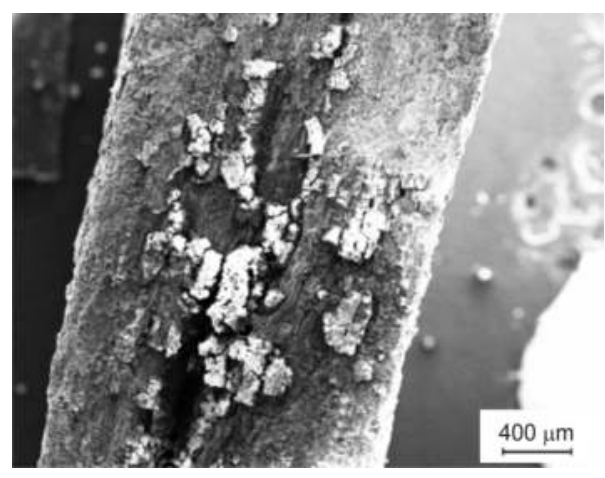

Figure 25. Cracked layer of corrosion products with banding-like arrangement in the X6MnSiAl26-3-3 steel after bending and immersion in $1 \mathrm{~N} \mathrm{H}_{2} \mathrm{SO}_{4}$.

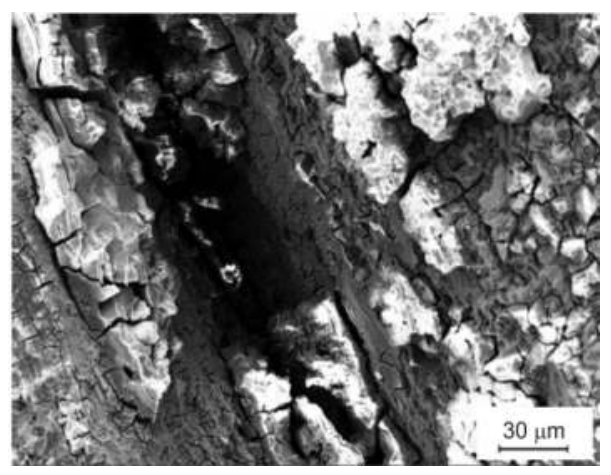

Figure 26. Cracked layer of corrosion products and deep corrosion decrements in the X6MnSiAl26-3-3 steel after bending and immersion in $1 \mathrm{~N} \mathrm{H}_{2} \mathrm{SO}_{4}$. 


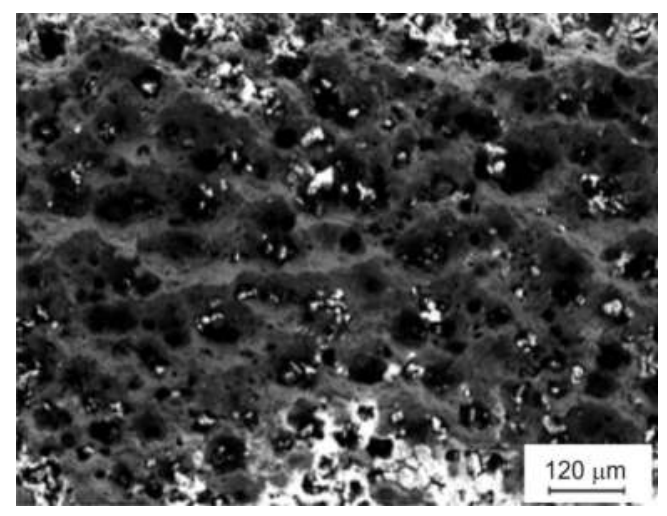

Figure 27. Numerous craters formed due to corrosion pitting and probable hydrogen impact in the X6MnSiAl26-3-3 steel after bending and immersion in $1 \mathrm{~N} \mathrm{H}_{2} \mathrm{SO}_{4}$.

The micrographs in Figures 25 and 26 reveal deep corrosion decrements and band-arranged corrosion products in a surface area. The corrosion products layer is not continuous and has many cracks (Fig. 26). Besides corrosion products, numerous craters formed due to intensive corrosion pitting and probably as a result of hydrogen impact are characteristic (Fig. 27). Craters forming is accompanied by local cracking of corrosion products layer (Fig. 26), uncovering the metal surface and causing further penetration of the corrosive medium and finally the intensive progress of general and pitting corrosion.

Generally Hydrogen Induced Cracking (HIC) is not a problem in austenitic steels because of the relatively low diffusion coefficient of $\mathrm{H}$ in a FCC lattice (Kumar \& Balasubramaniam, 1997). However, enhanced permeation of hydrogen was observed in cold worked austenitic steels by Kumar \& Balasubramaniam (1997), what was attributed to a strain-induced martensitic transformation leading to promote hydrogen diffusion as the diffusivity is much higher in the bcc martensite lattice. Additionally, hydrogen mobility is enhanced by the presence of high-dislocation density due to cold working (Ćwiek, 2010). The hydrogen induced surface cracking at the high hydrogen concentration places, i.e. grain and twin boundaries, $\varepsilon / \gamma$ interface was also observed in stainless steels during hydrogen effusion from the supersaturated sites (Yang \& Luo, 2000). Especially privileged to surface hydrogen accumulation is $\varepsilon$ martensite. It was observed in a X5MnSiAl25-4-2 high-Mn steel containing lamellar plates of $\varepsilon$ martensite (Grajcar et al., 2010). Atomic hydrogen absorbed in the surface area penetrates the steel and accumulates in places with non-metallic inclusions, lamellar precipitations of the second phase, microcracks and other structural defects, where convenient conditions for recombining of atomic hydrogen to molecular $\mathrm{H}_{2}$ exist. The recombination of atomic hydrogen to molecular state is a very exothermic reaction, which provides a pressure increase in formed $\mathrm{H}_{2}$ bubbles as well as nucleation and growth of microcracks in a surface region of the sample. In the investigated X6MnSiAl26-3-3 steel the evident microcraks associated with HIC were not revealed but observed corrosion damages in a surface area (Figs. 24-27) are a result of a combined contribution of general corrosion, pitting and hydrogen impact. 


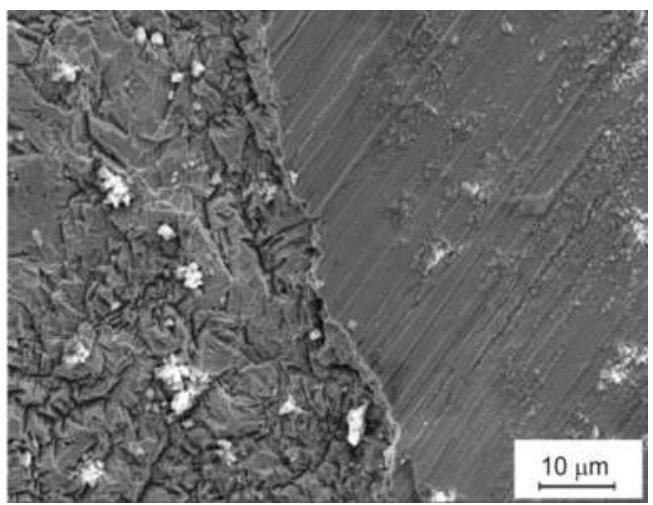

Figure 28. The boundary between undipped and dipped parts of the sample showing a scaled and cracked layer of corrosion products in the X6MnSiAl26-3-3 steel after bending and immersion in $3.5 \mathrm{wt} \% \mathrm{NaCl}$.

A layer of corrosion products protecting the metal against continuous penetration of a corrosive medium is forming on the surface of specimens dipped in a chloride solution (Fig. 28). The formed scaled layer strongly adheres to the steel though numerous surface cracks occurring. Corrosion cracks were not observed as distinct from a steel containing $\varepsilon$ martensite plates (Grajcar, 2012). The created surface layer of corrosion products protects effectively the base metal against chloride medium even after cold deformation because the mass decrement is comparable to that obtained for non-deformed samples (Table 3). In turn, cold deformation rises slightly the mass loss in the acidic medium in comparison with the specimens investigated in an initial state (Table 3). The effect of cold deformation on the acceleration of mass losses was much higher for the stainless steel (Table 2) probably due to the occurrence of $\alpha^{\prime}$ martensite forming a local corrosive galvanic cell with the austenitic matrix. The enhancement of the corrosion progress in the high-Mn steel immersed in the acidic solution can be only related to annealing twins showing a different potential than the matrix (Ghayad et al., 2006; Mazancova et al., 2010).

\section{Summary}

The dynamic development of technology creates the necessity for producing steels combining high strength, toughness and ductile properties with high corrosion resistance. The austenitic alloys possess an exceptional balance of strength and ductility as well as the high ability to further rise their strength during technological forming or cold rolling. These properties decide about their wide application in the chemical, machinery, food, automotive, nuclear and shipbuilding industries. Although austenitic stainless steels are characterized by excellent resistance to general corrosion, they are susceptible to the localized corrosive attacks, such as pitting corrosion, intergranular corrosion and stress corrosion cracking (SCC) in chloride and sulfuric environments. The high-manganese austenitic alloys 
can be also an option for some applications but generally their corrosion resistance is much lower.

The results presented in this chapter focused on the evaluation of corrosion behaviour of plastically deformed $\mathrm{Cr}-\mathrm{Ni}$ and high-Mn steels in acidic and chloride containing media. The results of immersion and potentiodynamic tests as well as microstructural studies prove that both examined steels are susceptible to corrosion attacks. However, the corrosion progress in the $\mathrm{Cr}-\mathrm{Ni}$ stainless steel requires stronger corrosive reagents and longer exposition time in corrosive environments compared to the steel alloyed with manganese.

The mass loss of the $\mathrm{X} 5 \mathrm{CrNi18}-8$ steel immersed in $3.5 \mathrm{~N} \mathrm{H}_{2} \mathrm{SO}_{4}$ is equal to about $40 \%$ and is over two orders of magnitude higher compared to the specimens dipped in the chloride solution. The similar difference in the corrosion progress was obtained for the high-Mn steel, though its real corrosion rate (taking into account test conditions) is much higher than that of the stainless steel. The fast progress of mass loss in the acidic solution is a result of the hydrogen depolarization, which is a typical corrosion mechanism under such conditions. Due to this process, numerous corrosion pits are formed and local cracking of corrosion products layer occurs resulting in penetration of the corrosive medium and finally leading to the intensive corrosion progress. In turn, the oxygen depolarization process results in formation of a layer of corrosion products on surfaces of the steels examined in the chloride medium limiting effectively a corrosion progress.

The cold working intensifies the corrosion progress especially in the $\mathrm{Cr}-\mathrm{Ni}$ steel as a result of formation of the strain-induced $\alpha^{\prime}$ martensite. The percentage mass decrements are near twice and three times higher correspondingly for the acidic and chloride solutions. The increase of the degree of plastic deformation from $10 \%$ up to $70 \%$ results in lowering the corrosion potential as well as higher values of corrosion current density. The pit forming and propagation in the $\mathrm{X} 5 \mathrm{CrNi18}-8$ steel are accelerated with increasing volume fractions of martensite. The corrosion rate and subsequent mass loss of the cold deformed high-Mn steel increase only slightly probably due to deformation twins forming.

In general, the low corrosion resistance of high-manganese steel is from the fact, that $\mathrm{Mn}$ forms unstable manganese oxide due to low passivity coefficient and hence reduces their electrochemical corrosion resistance (Kannan et al., 2008). It leads consequently to the high dissolution rate of $\mathrm{Mn}$ and $\mathrm{Fe}$ both in $\mathrm{H}_{2} \mathrm{SO}_{4}$ and $\mathrm{NaCl}$ solutions (Ghayad et al., 2006; Hamada, 2007; Kannan et al., 2008; Zhang \& Zhu, 1999). It seems that high-Mn steels can replace conventional austenitic stainless steels only partially in non-critical applications. Their corrosion resistance can be improved by surface engineering, i.e. zinc coatings or $\mathrm{Cr}$ alloying (Hamada, 2007; Mujica Roncery et al., 2010).

\section{Acknowledgement}

The work was partially financially supported by the NCN - The National Science Centre (grant No. 2632/B/T02/2011/40). 


\section{Author details}

Wojciech Ozgowicz, Agnieszka Kurc-Lisiecka and Adam Grajcar

Silesian University of Technology, Gliwice, Poland

\section{References}

[1] Abreu, H.; Carvalho, S.; Neto, P.; Santos, R.; Freire, V.; Silva, P. \& Tavares, S. (2007). Deformation induced martensite in an AISI 301LN stainless steel: Characterization and influence on pitting corrosion resistance. Materials Research, Vol.10, (2007), pp. 359-366

[2] Altstetter, C.J.; Bentley, A.P.; Fourine, J.W. \& Kirkbridge, A.N. (1986). Processing and properties of Fe-Mn-Al alloys. Materials Science and Engineering A, Vol.82 (1986), pp. $13-25$

[3] Azambuja, D.S.; Martini, E.M. \& Müller, I.L. (2003). Corrosion behaviour of iron and AISI 304 stainless steel in tungstate aqueous solutions containing chloride. Journal of the Brazilian Chemical Society, Vol.14, No.4, (2003), pp. 570-576

[4] Barbucci, A.; Cerisola, G. \& Cabot, P.L. (2002). Effect of cold working in the passive behavior of 304 stainless steel in sulfate media. Journal of Electrochemical Society, Vol. 149, (2002), pp. 534-542

[5] Baszkiewicz, J. \& Kamiński, M. (1997). Fundamentals of materials corrosion, The Warsaw University of Technology Publishers, Warsaw, Poland

[6] Briant, C.L. (1982). Effect of nitrogen and cold work on the sensitization of austenitic stainless steels. Electric Power Research Institute Report EPRI-NP-2457, Palo Alto, California

[7] Ćwiek, J. (2009). Hydrogen degradation of high-strength steel. Journal of Achievements in Materials and Manufacturing Engineering, Vol.37, (2009), pp. 193-212

[8] Ćwiek, J. (2010). Prevention methods against hydrogen degradation of steel. Journal of Achievements in Materials and Manufacturing Engineering, Vol.43, No.1, (2010), pp. 214-221

[9] De Cooman, B.C.; Chin, K. \& Kim, J. (2011). High Mn TWIP steels for automotive applications, In: New Trends and Developments in Automotive System Engineering, M. Chiaberge, (Ed.), pp. 101-128, InTech, ISBN 978-953-307-517-4, Rijeka, Croatia

[10] Fang, Z.; Wu, Y.S.; Zhang, L. \& Li, J. (1997). Effect of deformation induced martensite on electrochemical behaviors of type 304 stainless steel in the active state. Corrosion Science and Protection Technology, Vol.9, No.1, (1997), pp. 75-83 
[11] Frankel, G.S. (1998). Pitting corrosion of metals. A review of the critical factors. Journal of the Electrochemical Society, Vol.145, No.6, (1998), pp. 2186-2198

[12] Frommeyer, G. \& Bruex, U. (2006). Microstructures and mechanical properties of high-strength Fe-Mn-Al-C light-weight TRIPLEX steels. Steel Research International, Vol.77, No.9-10, (2006), pp. 627-633

[13] Frommeyer, G.; Bruex, U. \& Neumann, P. (2003). Supra-ductile and high-strength manganese-TRIP/TWIP steels for high energy absorption purposes. ISIJ International, Vol.43, No.3, (2003), pp. 438-446

[14] Fu, Y.; Wu, X.; Han, E.H.; Ke, W.; Yang, K. \& Jiang, Z. (2009). Effects of cold work and sensitization treatment on the corrosion resistance of high nitrogen stainless steel in chloride solutions. Electrochimica Acta, Vol.54, (2009), pp. 1618-1629

[15] Garcia, E.G.; Paniagua, F.A.; Herrera-Hernández, H.; Juárez Garcia, J.M.; Pardavé M.E. \& Romo, M.A. (2010). Electrochemical and microscopy study of localized corrosion on a sensitized stainless steel AISI 304. ESC Transactions, Vol.29, No.1, (2010), pp. 93-102

[16] Ghayad, I.M.; Hamada, A.S.; Girgis, N.N. \& Ghanem, W.A. (2006). Effect of cold working on the aging and corrosion behaviour of Fe-Mn-Al stainless steel. Steel Grips, Vol.4, No.2, (2006), pp. 133-137

[17] Graessel, O.; Krueger, L.; Frommeyer, G. \& Meyer, L.W. (2000). High strength FeMn-(Al, Si) TRIP/TWIP steels development - properties - application. International Journal of Plasticity, Vol.16, (2000), pp. 1391-1409

[18] Grajcar, A. (2012). Corrosion resistance of high-Mn austenitic steels for the automotive industry, In: Corrosion Resistance, H. Shih, (Ed.), pp. 353-376, InTech, ISBN 978-953-51-0467-4, Rijeka, Croatia

[19] Grajcar, A.; Kołodziej, S. \& Krukiewicz, W. (2010a). Corrosion resistance of highmanganese austenitic steels. Archives of Materials Science and Engineering, Vol.41, No. 2, (2010), pp. 77-84

[20] Grajcar, A.; Krukiewicz, W. \& Kołodziej, S. (2010b). Corrosion behaviour of plastically deformed high-Mn austenitic steels. Journal of Achievements in Materials and Manufacturing Engineering, Vol.43, No.1, (2010), pp. 228-235

[21] Grajcar, A.; Opiela, M. \& Fojt-Dymara, G. (2009). The influence of hot-working conditions on a structure of high-manganese steel. Archives of Civil and Mechanical Engineering, Vol.9, No.3, (2009), pp. 49-58

[22] Hamada, A.S. (2007). Manufacturing, mechanical properties and corrosion behaviour of high-Mn TWIP steels. Acta Universitatis Ouluensis C281, ISBN 978-951-42-8583-7, Oulu, Finland 
[23] Huang, B.X.; Wang, X.D.; Rong, Y.H.; Wang, L. \& Jin, L. (2006). Mechanical behavior and martensitic transformation of an Fe-Mn-Si-Al-Nb alloy. Materials Science and Engineering A, Vol.438-440, (2006), pp. 306-313

[24] International Iron \& Steel Institute (September 2006). Advanced High Strength Steel (AHSS) Application Guidelines - version 3, Available from http://worldautosteel.org

[25] Jimenez, J.A. \& Frommeyer, G. (2010). Microstructure and texture evolution in a high manganese austenitic steel during tensile test. Materials Science Forum, Vol.638-642, (2010), pp. 3272-3277

[26] Kamide, H.; Fujitsuka, K. \& Tanaka, Y. (1994). Effect of carbon content on dissolution rate of ' martensite and 304 stainless steel in a $\mathrm{H}_{2} \mathrm{SO}_{4}-\mathrm{NaCl}$ solution. Journal of the Japan Institute of Metals, Vol.58, (1994), pp. 1414-1419

[27] Kannan, M.B.; Raman, R.K.S., \& Khoddam, S. (2008). Comparative studies on the corrosion properties of a Fe-Mn-Al-Si steel and an interstitial-free steel. Corrosion Science, Vol.50, (2008), pp. 2879-2884

[28] Khatak, H.S. \& Raj, B. (2002). Corrosion of austenitic stainless steel: mechanism, mitigation and monitoring, Woodhead Publishing, ISBN 1-85573-613-6, London, UK

[29] Kumar, B.R.; Mahato, B. \& Singh, R. (2007). Influence of cold-worked structure on electrochemical properties of austenitic stainless steels. Metallurgical and Materials Transactions, Vol.38A, (2007), pp. 2085-2094

[30] Kumar, B.R.; Singh, R.; Mahato, B.; De, P.K.; Bandyopadhyay, N.R. \& Battacharya, D.K. (2005). Effect of texture on corrosion behavior of AISI 304L stainless steels. Materials Characterization, Vol.54, (2005), pp. 141-147

[31] Kumar, P. \& Balasubramaniam, R. (1997). Determination of hydrogen diffusivity in austenitic stainless steels by subscale microhardness profiling. Journal of Alloys and Compounds, Vol.255, (1997), pp. 130-134

[32] Kurc, A.; Kciuk, M. \& Basiaga, M. (2010). Influence of cold rolling on the corrosion resistance of austenitic steel. Journal of Achievements in Materials and Manufacturing Engineering, Vol.38, No.2, (2010), pp. 154-162

[33] Lee, T.H.; Oh, C.S.; Kim, S.J. \& Takaki, S. (2007). Deformation twinning in high-nitrogen austenitic stainless steel. Acta Materialia, Vol.55, (2007), pp. 3649-3662

[34] Lovicu, G.; Barloscio, M.; Botaazzi, M.; D’Aiuto, F.; De Sanctis, M.; Dimatteo, A.; Federici, C.; Maggi, S.; Santus, C. \& Valentini, R. (2010). Hydrogen embrittlement of advanced high strength steels for automotive use. Proceedings of International Conference on Super-High Strength Steels, pp. 1-13, Peschiera del Garda, Italy, October 17-20, 2010

[35] Mansur, L.K. \& Lee, E.H. (1990). A mechanism of swelling suppression in coldworked phosphorous modified stainless steels, Philosophical Magazine A, Vol. 61, (1990), pp. 733-749 
[36] Mazancova, E.; Kozelsky, P. \& Schindler, I. (2010). The TWIP alloys resistance in some corrosion reagents. Proceedings of International Conference METAL, pp. 1-6, Roznov pod Radhostem, Czech Republic, May 18-20, 2010

[37] Mujica Roncery, L.; Weber, S. \& Theisen, W. (2010). Development of Mn-Cr-(C-N) corrosion resistant twinning induced plasticity steels: thermodynamic and diffusion calculations, production and characterization. Metallurgical and Materials Transactions A, Vol.41A, No.10, (2010), pp. 2471-2479

[38] Ningshen, S. \& Kamachi Mudali, U. (2010). Pitting and intergranular corrosion resistance of AISI type 301LN stainless steels. Journal of Materials Engineering and Performance, Vol.19, No.2, (2010), pp. 274-281

[39] Oh, Y.J. \& Hong, J.H. (2000). Nitrogen effect on precipitation and sensitization in cold-worked type 316L(N) stainless steels. Journal of Nuclear Materials, Vol.278, (2000), pp. 242-250

[40] Opiela, M.; Grajcar, A. \& Krukiewicz, W. (2009). Corrosion behaviour of Fe-Mn-Si-Al. Journal of Achievements in Materials and Manufacturing Engineering, Vol.33, No.2, (2009), pp. 159-165

[41] Osawa, M \& Hasegawa, M. (1981). Stress corrosion cracking of hydrogen-containing austenitic stainless steel in $\mathrm{H}_{2} \mathrm{SO}_{4}-\mathrm{NaCl}$ solution. Transactions of the Iron and Steel Institute of Japan, Vol.21, (1981), pp. 464-468

[42] Otero, E.; Pardo, A.; Sáenz, E.; Utrilla, V. \& Pérez F. (1995). Intergranular corrosion behaviour of a new austenitic stainless steel low in nickel. Canadian Metallurgical Quarterly, Vol.34, (1995), pp. 135-141

[43] Pardo, A.; Merino, M.C.; Carboneras, M. \& Coy A.E. (2007). Pitting corrosion behaviour of austenitic stainless steels with $\mathrm{Cu}$ and Sn additions. Corrosion Science, Vol.49, (2007), pp. 510-525

[44] Peguet, L.; Malki, B. \& Baroux, B. (2007). Influence of cold working on the pitting corrosion resistance of stainless steels. Corrosion Science, Vol.49, (2007), pp. 1933-1948

[45] Qiao L.J. \& Luo J.L. (1998). Hydrogen-facilitated anodic dissolution of austenitic stainless steels. Corrosion Science, Vol. 54, No. 4, (1998), pp. 281-288

[46] Rutkowska-Gorczyca, M.; Podrez-Radziszewska, M. \& Kajtoch, J. (2009). Influence of cold working process on the corrosion resistance of steel 316L. SIM XXXVII, KrakówKrynica, (2009), pp. 319-323

[47] Shin, S.Y.; Hong, S.; Kim, H.S.; Lee, S. \& Kim, N.J. (2010). Tensile properties and cup formability of high Mn and Al-added TWIP steels. Proceedings of International Conference on Super-High Strength Steels, pp. 1-9, Peschiera del Garda, Italy, October 17-20, 2010 
[48] Sing M.K. \& Kumar A. (2011). Environmental corrosion studies of cold rolled austenitic stainless steel. International Journal of Advanced Scientific and Technical Research, Vol.2, No.1, (2011), pp.470-482

[49] Sing V.B. \& Ray, M. (2007). Effect of $\mathrm{H}_{2} \mathrm{SO}_{4}$ addition on the corrosion behaviour of AISI 304 austenitic stainless steel in methanol-HCl solution. International Journal of Electrochemical Science, Vol.2, (2007), pp.329-340

[50] Sunada, S.; Kariba, M.; Majami, K. \& Sugimoto, K. (2006). Influence of concentration of $\mathrm{H}_{2} \mathrm{SO}_{4}$ and $\mathrm{NaCl}$ on stress corrosion cracking of SUS304 stainless steel in $\mathrm{H}_{2} \mathrm{SO}_{4}$ $\mathrm{NaCl}$ aqueous solution. Materials Transactions, Vol. 47, No.2, (2006), pp.364-370

[51] Sunada, S.; Nakamura, N.; Kawase, H.; Notoya, H.; Sanuki, S. \& Arai, K. (1991). Effect of deformation-induced martensite on the general corrosion of SUS304 stainless steel in $\mathrm{H}_{2} \mathrm{SO}_{4}-\mathrm{NaCl}$ solution. Journal of the Japan Institute of Metals, Vol. 55, No.6, (1991), pp.1078-1089

[52] Štefec, R. \& Franz, F. (1978). A study of the pitting corrosion of cold-worked stainless steel. Corrosion Science, Vol.18, No.2, (1987), pp.161-168

[53] Xu, C. \& Hu, G. (2004). Effect of deformation-induced martensite on pit propagation behavior of 304 stainless steel. Anti-Corrosion Methods and Materials, Vol.51, (2004), pp. 381-388

[54] Yang, Q. \& Luo, J.L. (2000). Martensite transformation and surface cracking of hydrogen charged and outgassed type 304 stainless steel. Materials Science and Engineering A, Vol.288, (2000), pp. 75-83

[55] Zhang, Y.S. \& Zhu, X.M. (1999). Electrochemical polarization and passive film analysis of austenitic Fe-Mn-Al steels in aqueous solutions. Corrosion Science, Vol.41, (1999), pp. 1817-1833

[56] Zhilin, L.; Wei, L. \& Juncai Q. (2006). The effect of electrochemically induced annealing on the pitting resistance of metastable austenitic stainless steel. Metallurgical and Materials Transactions, Vol.37A, No.2, (2006), pp. 435-439 
